\title{
Formulation Policy against Religious Offenses and Insult to God in the Effort to Reform Criminal Law
}

\author{
Ino Susanti ${ }^{1}$, Ratna Kumala Sari ${ }^{2}$ \\ \{inosusati22@gmail.com ${ }^{1}$, ratnakumala92@gmail.com² ${ }^{2}$ \\ Faculty of Law, Sang Bumi Ruwa Jurai University, Bandar Lampung,Indonesia ${ }^{1}$, Faculty of Law, Sang \\ Bumi Ruwa Jurai University, Bandar Lampung, Indonesia ${ }^{2}$
}

\begin{abstract}
There is no special chapter that regulates offenses against religion and offenses related to religion. Based on this, several problems can be formulated, namely how to formulate policies against religious offenses and insult God in Indonesian positive law today and how to formulate policies for religious offenses and insult God in the future. This research uses a normative juridical approach which refers to secondary data and is supported by a historical juridical approach and a comparative juridical approach. The results of the study concluded that currently the formulation of criminal law policies against religious offenses is contained in the Criminal Code and special laws outside the Criminal Code. Meanwhile, the Criminal Code Bill, which is currently being discussed, has formulated the religious offense in a firm and detailed manner, so that it can accommodate deficiencies in the current legislation if it is passed in the future.
\end{abstract}

Keywords: formulation policy, religious offenses and insulting God, criminal law reform

\section{Introduction}

Based on the First Principle of Pancasila, which reads Almighty Godliness, the Indonesian state is a country that places religion as the main itself in the life of the nation and state. Then in Article 29 paragraph (1) of the Basic Law it is reaffirmed which reads that "the State is based on One Godhead" and in Article 29 paragraph (2) it reads "The state guarantees the freedom of every citizen to embrace their respective religions and to worship according to his religion and belief.

Freedom of religion is one of the most fundamental rights of all, because religious freedom is directly rooted in the dignity of humans as God's creatures. Thus the state must guarantee freedom for everyone to embrace their respective religions and to worship according to their religion and belief [1].

In the context of the administration of the Unitary State of the Republic of Indonesia which was declared in 1945 which has laid the foundation on which religion is an integral part of state administration, but does not explicitly state that the Republic of Indonesia as a religious state has an impact that the number of crimes or crimes against religion is increasing day by day with all its form and mode of operation, and even blasphemy of religion have triggered conflicts between religious believers and ideological conflicts of freedom that have resulted in disharmony in international relations, damage and even death of innocent people $[2]$.

According to Muladi, the regulation on criminal acts against religion and religious life or "religious offenses" in Indonesia is a reflection that Indonesia is a religious "Nation State". In this regard, Soehino stated that one of the characteristics of the Pancasila rule of law is a 
religious nation state, namely in seeing the relationship between the state and religion the concept of a Pancasila rule of law does not adhere to secularism but is also not a religious state as in theocracy and in the concept of Islamic Monocracy.

Resilience to formulation is the most strategic stage of the entire policy process to operationalize or functionalize laws and regulations (especially in the context of crime prevention). It is said so because at this stage policy lines are formulated and there is a process of criminalization and a process of penalization which will become the basis of legality (as a benchmark in determining or knowing with certainty and clearly about the prohibited and punishable acts). This of course will also affect or affect the application and execution stages in legal practice [3].

Based on the above background and looking at the development of criminal acts against religion, in relation to this writing formulates the following problems, first, what is the formulation policy for religious offenses and insulting God in today's positive law? and second, what is the formulation policy towards religious offenses and insulting God in the future?

The purpose of this study is to describe and analyze the formulation of blasphemy against religious offenses and God's insult today and in the future.

\section{Literature Review}

Religion has important meaning for the people and nation of Indonesia. Since ancient times, our ancestors had the view that life was not only life in the world but there was another life afterward, recognized the belief in the existence of spirits, in short, they believed in the existence of something that was considered supernatural. These are the seeds of a growing religious attitude and exist today

The determination and formulation of religious offenses in Indonesia that recognize a relationship between state and religious unity raises issues that need attention in the reform of criminal law. To explain the conceptual basis or theoretical basis regarding the need to criminalize religious offenses, theories of religious offenses are needed. The theories of religious offenses put forward by Oemar Seno Adji as quoted by Barda Nawawi Arief, include:

- Religionsshucts Theorie

According to this theory, religion itself is seen as a legal interest or object to be protected (which is deemed necessary to be protected) by the state, through the laws it makes.

- Gefuhsschutz Theorie

According to this theory, the legal interests that will be protected are the religious feelings / feelings of religious people.

- Friedensshuctz Theorie

The object or legal interest protected according to this theory is "peace/peace of interconfessional religion (among followers of religions/beliefs)" or what in German terms is called "der religious interkonfessionelle Friede" so it is more focused on public order that will be protected.

The aforementioned several theories regarding religious offenses are intended to be used as a basis in determining and formulating religious offenses in the framework of reforming criminal law. The theory of religious offenses is based on an understanding of how to protect legal interests with criminal law. 


\section{Methods}

Based on the formulation of the problem and the research objectives, it can be seen that the main problem in this study includes one of the criminal law policies, especially the formulation policy in formulating religious offenses and insults. Therefore, the approach used is a policy-oriented approach. However, because the main purpose of this research lies in the issue of legislative policy, namely regarding legislation in determining and formulating religious offenses and insulting God, the type of research in the preparation of this paper is normative legal research which refers to secondary data and is supported by a historical juridical approach. and comparative juridical [4]. The approach to be used is the statutory approach which is also used to examine problems normatively from the perspective of the ius constitutum and ius constituendum related to religious offenses and insulting God. Approaches to the laws and regulations relating to this writing are the Criminal Code (KUHP) and the Draft Criminal Code (RUU KUHP). Sources of legal materials used in this study consist of primary legal materials, secondary legal materials, and tertiary legal materials. The technique of collecting legal materials is using document techniques, namely by collecting existing literature studies on secondary legal materials. Then the data collected is then analyzed using qualitative methods that are supported by deductive logic in response to all legal problems that exist in this paper.

\section{Results And Discussion}

\subsection{Formulation Policy Against Religious Offenses and Insult to God in Current Positive Law}

Indonesian criminal law as a legal system which is an adoption of Dutch law in determining a criminal act or the violation of an act is to use Article 1 paragraph (1) of the Criminal Code which is known as the legality principle [5].

The current Criminal Code does not have a special chapter on religious offenses, although there are several offenses that can be categorized as religious offenses in three definitions, namely: 1) criminal offenses/offenses "according to religion"; 2) a criminal act / offense "against religion"; and 3) criminal offenses/offenses "related to religion" or "against religious life". In the Criminal Code there is also no explicit formulation of the offense against God.

The application of religious offenses in the Criminal Code is categorized as a crime against public order (see Book II Chapter V). Article 156a of the Criminal Code which is the main article stands for Article 3 jo. Articles 1 and 2 of Law No.1 Pnps Year 1965 which constitute the background for religious offenses to be included in the Criminal Code.[6]

Meanwhile, offenses related to religion are spread in several special laws outside the Criminal Code, including Article 18 paragraph (2) jo. Article 13 of Law Number 40 of 1999 concerning the Press and Article 57 jo. Article 36 paragraph (6), Article 58 jo. article 46 paragraph (3) of Law Number 32 Year 2002 concerning Broadcasting.

The current criminal law formulation policy that regulates religious offenses is the Criminal Code and special laws outside the Criminal Code (Press Law and Broadcasting Law). However, it contains a weakness, namely that religious offenses are categorized as crimes against public order. 


\subsection{Formulation Policy against Religious Offenses and Insult to God in the Future}

The Criminal Code currently in effect in Indonesia is a criminal code book which is a legacy of the Dutch East Indies era government. Therefore, the desire to have a national KUHP has been initiated for a long time and has become something that is coveted. This desire was then "translated" with the holding of a National Law Seminar and held in 1963. The national law seminar was the first legal reform seminar, and among them resulted in a decision in the form of a resolution that urged the government to immediately form a national KUHP to replace the KUHP (WvS ) Dutch heritage [7].

As a manifestation of the penal reform policy, it is normal for the Criminal Code concept to review the policy of the Criminal Code inherited from the Dutch era which places religiousrelated offenses as part of the offense against "public order". From various inputs, especially from Alm. Prof. Oemar Senoadji, finally agreed to make a special chapter on "crimes against religion and religious life" in the concept of the Criminal Code. Such policies can also be seen in the conclusions and recommendations of the Symposium "The Influence of Culture and Religion on Criminal Law" in Bali in 1975[8].

Efforts to reform the National Criminal Law are still ongoing and up to the 2019 Criminal Code Bill. From several formulations in the Draft Criminal Code, it appears that these reform efforts, in addition to trying to absorb national thoughts and socio-cultural values on a human basis, Indonesian nature and traditions, which are reflected in Pancasila and the 1945 Constitution, also try to adapt to universal / international tendencies.

Regulations regarding religious offenses included in the 2019 Criminal Code Bill can be found in CHAPTER VIII entitled "Criminal Actions against Religion and Religious Life". The provisions are as follows:

Article 304

Every person in public who expresses feelings or commits an act of enmity or blasphemy against the religion adopted in Indonesia shall be punished with imprisonment of up to 5 (five) years or a maximum fine of Category V.

\section{Article 305}

(1) Any person broadcasting, showing, pasting writings or pictures, or broadcasting a recording, including disseminating it through information technology facilities containing the Crime as referred to in Article 304, with the intention that the contents of the text, picture or recording are known or more. It is known that the public is sentenced to imprisonment of 5 (five) years or a maximum fine of Category $\mathrm{V}$.

(2) If any person as referred to in paragraph (1) commits said act in carrying out his profession and at that time it has not passed 2 (two) years since the sentencing decision which has obtained permanent legal force for committing the same Crime, then he may be sentenced to addition in the form of revocation of rights as referred to in Article 86 letter $\mathrm{f}$.

Article 306

Any person who publicly incites in any form with the intention of negating a person's belief in any religion practiced in Indonesia shall be punished with imprisonment of up to 4 (four) years or a maximum fine of Category IV. 
Article 307

(1) Anyone who by Violence or Threats of Violence disturbs, obstructs, or dissolves a religious meeting shall be punished with imprisonment of 2 (two) years or a maximum fine of Category III.

(2) Any person who with Violence or Threats of Violence disturbs, obstructs, or disbands a person who is carrying out religious services or ceremonies shall be punished with imprisonment of up to 5 (five) years or a maximum fine of Category V.

(3) Any person who makes noise near the building where the worship is held while the worship is in progress shall be subject to a maximum fine of Category I.

Article 308

Anyone who publicly commits insult to a person who is running or leading an organization of worship shall be punished with imprisonment of up to 2 (two) years or a maximum fine of Category III.

Article 309

Any person who defiles or illegally damages or burns the building of a place of worship or any object worn for worship, shall be punished with a maximum imprisonment of 5 (five) years or a maximum fine of Category $\mathrm{V}$.

Furthermore, efforts to embody the formulation of criminal law policies, policy makers (legislators) should conduct comparative studies with other countries. According to Rene David and Brierley in Barda Nawawi Arief [9] the benefits of comparative law are:

a. Useful in historical and philosophical legal research;

b. It is important to understand better and to develop our own national laws;

c. Helping in developing understanding of other nations and therefore contributing to creating a good relationship / atmosphere for the development of international relations.

The opinion of Rene David and Brierley shows that legal comparison is not only useful in legal research, but also can be a means for developing national law and strengthening international cooperation. There is a comparison with the legal systems of other countries, so that the similarities and differences will be known, so that they can be used as material for consideration or input into the national legal system.

Through a comparative approach or a comparative approach both regarding the comparison of legal systems between countries, as well as comparisons of legal products and legal character across countries, this study compares legal products related to the formulation of religious offenses in several countries so that the comparison with the formulation will be seen in Indonesia.

Several countries have implemented rules regarding religious offenses in their positive laws, including the following:

1) Armenian Criminal Code

In Armenia there is no special chapter on religious offenses. Offenses related to religion are scattered in several articles, namely:

a. In Chapter 19 (Crimes against constitutional human rights and freedoms of citizens):

- Violating human rights and freedoms based on reasons of nationality, race, sex, language, religion, politics or other views, social origins, wealth or other status (regulated in Article 143 Breach of citizens' legal equality) 
- Obstructing the right to carry out religious ceremonies or legal activities of religious organizations (regulated in Article 160. Hindrance to the right to exercise freedom of conscience of religion);

b. In Chapter 33 (Crimes against peace and human security), there is Article 392 which regulates crimes against the security and peace of a person based on religion.

\section{2) Latvian Criminal Code}

In Latvia there is no special chapter on religious offenses. Offenses related to religion are scattered in several articles in Chapter XIV: Criminal Offences against Fundamental Right and Freedoms of a Person, which include:

a. Violation of equal rights of people based on their attitudes towards religion (Section 150. Violation of Equality Rights of Persons on the Basis of their Attitude towards Religion);

The bottom line:

Directly or indirectly, limiting the things or choices of a person based on the basis of religious attitudes, except for activities in institutions of religious sects / groups, or

Committing an offense against someone's religious taste or

Inciting hatred in relation to people's attitudes towards religion or towards atheism

b. Interfering with religious ceremonies (Section 151. Iinterference with Religious Rituals).

The bottom line:

Intentional interference (interference) with religious rituals, if it is not against the law and is not related to violations of personal rights.

3) Polish Criminal Code

The scope of religious offenses regulated in Chapter 28 (Offences against freedom of Conscience and Religion), includes:

a. Limiting citizens' rights to religious membership (Article 192);

b. Publicly insult, ridicule, demean groups or individuals of a religious affiliation / membership, or carry out active attacks (Article 193);

c. In carrying out religious rituals and functions, abusing religious freedom to damage / harm the interests of the Republic of Poland (Article 194);

d. In taking advantage of one's religious beliefs, misleading others or causing disturbance of public order (Article 195);

e. Forcing other people to carry out religious activities / ceremonies or to take part or not participate in religious activities / ceremonies (Article 196);

f. Intentionally disturbing funeral services, desecrating corpses, ashes or resting places of the dead, or destroying bodies / graves / other resting places (Article 197);

g. Hurting the religious feelings of others by insulting objects for worship or places of religious ceremonies (Article 198).

Based on the aforementioned provisions, the formulation of religious offenses has been regulated in detail and in detail in the Draft Law on the Criminal Code (RUU KUHP) 2019. The formulation of criminal law defines crimes against religion and those related to religion or life religious.

\section{Conclusion}

Based on the discussion that has been described, them the conclusions can be formulated as follows: 1) Currently the formulation of criminal law policies against religious offences are 
contained in criminal code and special laws out side the crimonal code. Need a regulation that set clearly to strengthen regarding religious offences such as Criminal Actions Against Religion and Religious Life, and 2) Trought a comparative approach regarding the comparison of legal systems will related to the formulation of religious offenses in Indonesia.

\section{Reference}

[1] I. Amin, "KEBIJAKAN FORMULASI HUKUM PIDANA TERHADAP PENANGGULANGAN DELIK AGAMA DALAM RANGKA PEMBAHARUAN HUKUM PIDANA," Ius, vol. 2, no. 6, pp. 526-537, 2014.

[2] Mudzakkir, "Tindak Pidana Terhadap Agama Dalam Kitab Undang- Undang Pidana ( Kuhp ) Dan Undang-Undang Tentang Pencegahan Penyalahgunaan Dan / Atau," Pusat Perencanaan Pembangunan Hukum Nasional BPHN Kementerian Hukum dan Hak Asasi Manusia, Jakarta, 2010.

[3] A. H. Zulkarnaen, K. Kristian, and M. R. Aridhayandi, "Kebijakan Formulasi Delik Agama dalam Kitab Undang-Undang Hukum Pidana yang Baru," Al-Ahkam J. Ilmu Syari'ah dan Huk., vol. 3, no. 1, p. 27, 2018, doi: 10.22515/al-ahkam.v3i1.1338.

[4] R. H. Soemintro, Metode Penelitian Hukum dan Jurimetri. Jakarta: Ghalia Indonesia, 1990.

[5] Hanafi, "Ladasan Filosofis Kebijakan Formulasi Kejahatan Terhadap Jenazah dalam Pasal 180 KUHP," Huk. dan Keadilan Voice Justisia, vol. 3, no. 1, pp. 73-95, 2019.

[6] N. Nurdin, "Delik Penodaan Agama Islam Di Indonesia," Int. J. Ihya' 'Ulum al-Din, vol. 19, no. 1, p. 129, 2017, doi: 10.21580/ihya.18.1.1745.

[7] Soedarto, "Perkembangan Ilmu Hukum dan Politik Ilmu Hukum," Masal. Huk., vol. 17, p. 6 , 1987.

[8] B. N. Arief, Delik Agama dan Penghinaan Tuhan (Blasphemy Di Indonesia dan Perbandingan Berbagai Negara. Semarang: Badan Penerbit Universitas Diponegoro, 2008.

[9] B. N. Arief, Perbandingan Hukum Pidana. Jakarta: PT RajaGrafindo, 2003. 